\title{
INFLUENCE OF GOVERNMENT CREDIT RISK ON PPP PROJECTS IN OPERATION STAGE
}

\author{
Yining ZHOU, Jicai LIU* \\ School of Economics and Management, Southwest Jiaotong University, Chengdu, China
}

Received 28 April 2020; accepted 23 November 2020

\begin{abstract}
In PPP projects, insufficient risk management may lead to the breakdown of partnerships and even project failures. Among them, the government credit risk is regarded as unbearable risk and a key risk affecting PPP projects because of its high frequency and impact. Therefore, based on the contractual relationship between both sides, a principal-agent model for the optimal choice of investors and the government under the government default probability is constructed. This paper explored the quantity relationship of the government credit risk and the project utility through analysing the effect of government default probability perceived by both parties on the investor's optimal effort level and government allocation ratio. The results demonstrate that the government credit risk will decrease the effort level of investors and have a negative impact on the utility of the project. Furthermore, the government's modification of the contract allocation ratio based on its own credit rating can offset the negative impact of its credit risk on the effectiveness of the project. But this regulatory effect is limited. The findings effectively provide some insights and theoretical basis for solving the negative effects of government credit risk.
\end{abstract}

Keywords: PPP project, government credit risk, project utility, game theory, operation stage.

\section{Introduction}

Public infrastructure is generally considered low efficiency in construction and operation, wasting natural and financial resources. Public infrastructure construction and operating costs are hard to make up for by revenue, resulting in government financial burden (Ehrhardt \& Janson, 2010). In this scenario, Public private partnership (PPP) model is widely used in the field of public infrastructure (Song et al., 2018; Regan et al., 2009; Tang et al., 2010). Because it not only can solve the financial pressure of government infrastructure by using social capital (Zhang, 2005; Yuan et al., 2010), but also can improve operational efficiency by introducing social management experience (Cheng et al., 2016; Zhang et al., 2016). However, PPP large-scale infrastructure projects are embedded with many features, such as huge scales, long cycles and great uncertainty. Therefore, PPP projects may face many risks, such as government credit risks, construction risks, market risks and operational risks (Bing et al., 2005). Among them, the government credit risk is regarded as unbearable risk and a key risk affecting PPP projects because of its high frequency and impact (Keers \& van Fenema, 2018).
In the preparation of PPP projects, the government usually promises investors high returns and guarantees to ensures project viability and participation of the investors in a turbulent investment environment (Chen, 2009; Ke et al., 2010), such as high return of fixed investment, tax incentives, long concession contract, etc. However, during the operation, the government may not follow the promise due to changes in the internal and external environment. Then it leads to the government credit risk and often occurs in real cases. For example, in the PPP project of Delhi Airport Express Line, the government refused to provide assistant as promised when the project fallen in trouble. And investors used incomplete contracts to claim compensation from government. The cooperation relationship broke down eventually (Gao et al., 2017). In the PPP project of Citong Bridge in China, the government promised the guarantee of restrictive competition to project company. But a few years later two new bridges were built nearby and competed with the Citong Bridge, which made it impossible for the project company to recover the cost (Song et al., 2009). There are many uncertainties caused by the turbulence in the internal and external environment

*Corresponding author. E-mail: jicailiu@126.com

Copyright $\odot 2021$ The Author(s). Published by Vilnius Gediminas Technical University

This is an Open Access article distributed under the terms of the Creative Commons Attribution License (https://creativecommons.org/licenses/by/4.0/), which permits unrestricted use, distribution, and reproduction in any medium, provided the original author and source are credited. 
will impact the behavior of the government default. When the external environment or policy of the project changes, the government is more inclined to default to get inflows to ease debt or fiscal pressure.

The government credit reflects the possibility of the government default based on the government's fiscal capacity and the history of the government default (Levy \& Pauzner, 2014). Low government credit indicates greater government credit risk. And then the occurrence of government credit risk will further reduce government credit. The higher probability of default will result in more losses to investors. This will lead to high prices, high financing costs, and opportunistic behavior of investors in PPP projects, and then leading to the reduction of the project utility and social welfare. Government credit risk has seriously restricted the progress of PPP projects and hindered the sustainable development of PPP model (Ryan, 2007).

Therefore, it is necessary to reveal the internal transmission mechanism of government credit risk and open the "black box" of government credit impact on project (Kadefors, 2004). Given the relationship forged by governments (as a principal) and private investors (as an agent), models are constructed to design the optimal contract arrangements in the government credit risk scenarios using principal-agent theory to explore the quantity relationship of the government credit risk and the project utility.

The paper is organized as follows: Section 1 reviewed the literatures on the root causes and impact of the government credit risk. Section 2 established and calculated the game model. And then section 3 analyzed and discussion the impact of the government credit risk to the project. A numerical simulation is performed in section 4 to briefly illustrate and demonstrate the analysis of this article. Last section put forward suggestions according to the analysis results.

\section{Literature review}

PPP projects always face critical risks because there are many uncertainties in long concession period (Bing et al., 2005). Insufficient risk management may lead to the breakdown of partnerships (Uiterwijk et al., 2013) and even project failures (Soomro \& Zhang, 2016). In the preparation of PPP projects, the government usually promises investors high returns and guarantees to attract investors to participate in PPP projects (Chen, 2009; Ke et al., 2010). However, too many guarantees provided by the government would decrease social welfare, increase project financing costs and the government fiscal pressure, finally induce government credit risks (Wibowo et al., 2012). More than this, some governments made unrealistic guarantees to investors and even disguised some unsuitable construction projects as PPP projects to improve their administrative performance (Wang et al., 2000). These projects tend to have low profits, poor returns and unable to cover costs, which increases the possibility of government credit default (Sachs et al., 2007). In addi- tion, although some governments choose PPP projects to improve operational efficiency, innovative technology and management skills, others choose PPPs because of fiscal deficits, budget pressures, and supply and demand gaps (Chowdhury et al., 2011). The government budget deficit and subsidy overrun will also produce the hidden danger of credit default (Iossa \& Martimort, 2015). In Indonesia, the political risk perception for PPP projects is relatively high due to exist of the country's legal and regulatory risk and government breach of contract (Voelker et al., 2008). In China, the risks related the government account for three of the top four in risk rankings according the tworound Delphi survey with practitioners (Ke et al., 2011). In Singapore, which is widely regarded as politically stable, unstable government behavior is seen as the fifth most critical risk factor in adopting PPP projects given a long concession period (Hwang et al., 2013). The credit default of local public sectors has become a formidable force to cause termination in several cases (Yang et al., 2019). And government credit risk has seriously restricted the progress of PPP projects and hindered the sustainable development of PPP model (Ryan, 2007). Therefore, the credit risk is regarded as a key risk and needed to manage carefully (Keers \& van Fenema, 2018).

In terms of managing credit risk, it is important to establish a complete credit system (Marques \& Berg, 2012). The credit rating reflects the probability of default on the government (Levy \& Pauzner, 2014) because it contains a comprehensive evaluation of the government's ability to perform (objective facts) and willingness to perform (subjective ideas). Therefore, the credit rating can help investors to distinguish the government credit information to avoid the tale of Gresham's law. And many scholars have conducted a profound study on the estimation of default probability and credit risk. Grammenos et al. (2008) proposed a binary logit model to predict the probability of default for high yield bond issued by shipping companies. Tserng et al. (2012) predicts contractor default by employing three option-based credit models (BSM, CB, and BS) based on stock market information. In PPP projects, Kong et al. (2008) used a conditional credit rating transition matrix to predict default probability in project finance. $\mathrm{Li}$ et al. (2017) presented a structural model and calibrated using market data to estimate the default probability of a project company in a PPP project. Wang et al. (2019) proposed a quantitative analysis method to estimate the project credit risk under a certain confident level based on Credit Metrics model and Monte Carlo simulation technique. The government credit rating system is becoming more and more comprehensive and accurate with the calculation of various probability of default (Tserng et al., 2011, 2012). However, due to the features of PPP projects, some projects are monopolistic and expected to have high profit. Investors may cooperate with low-credit governments to obtain high returns. In this scenario, it still cannot completely prevent low-credit governments from entering the market through establishing a thorough 
credit rating system. Therefore, it is necessary to reveal the internal transmission mechanism of government credit risk and open the "black box" of government credit impacts on project in public-private partnership.

Credit ratings reflect investors' perception of the probability of a government default and government credit risk. Investors can choose different strategy according to the perception of the probability of a government default. Some researchers have studied bank loan under PPP project finance, and it was found that credit risks critically impacted on loan spreads (Blanc-Brude \& Strange, 2010; Girardone \& Snaith, 2011) because the low credit rating prevents project from raising funds with low capital costs. In addition, a higher probability of default will cause investors to reduce the proportion of capital and increase the proportion of debt, which will lead to higher financing costs (Li et al., 2017). Worse still, in the preparation stage of PPP projects, a higher probability of default will cause investors to have more expected losses. This will result in more requirements and higher prices for investors when bidding (Lara-Rubio et al., 2017). In summary, low credit rating has resulted in unfavorable loan terms and weak negotiation power that significantly affect the bankability and value for money of PPP projects. However, the above scholars only studied the impact of government credit risk on the project from the perspective of financial feasibility. There are few studies to discuss the impact of government credit risk on the project during the operation stage. And these studies did not consider the impact of the endogenous behaviors of the investors aiming at maximizing the profits on the project. In the project operation stage, given the principal-agent relationship between investors and the government in PPP projects, high credit risk may lead to the opportunistic behavior of investors, such as reducing the level of effort and the cost of investment, leading to the reduction of the quality of the project products or services. Therefore, this paper tries to explore the quantitative impact of government credit risk on the project utility and design the optimal contract arrangements in the government credit risk scenarios using game theory.

\section{Model assumptions and calculations}

\subsection{Model assumptions}

In PPP projects, the government and investors make strategic choices according to the utility that can measure costs and benefits. The utility theory is used to evaluate the project feasibility from both financial and nonfinancial aspects before the implementation (Yan et al., 2011), identify and assess the potential risks faced by investors (Kang \& Feng, 2009), determine a reasonable project ceiling price (Wang, 2002). It is widely used in PPP project research because it can analyze various behavior choices and decision-making problems caused by uncertainty. Therefore, according to the utility theory, game models of investors and government credit under the condition of excess revenue during the operation period of PPP project are established. From the results of the model, the change of investors' effort level and the impact on the project utility are analyzed, and the role path of government credit on the value promotion of PPP project is studied. And the next step is to make some practical basic assumptions before establishing the model.

Assumption 1. The government and investors are rational. And their risk preference is neutral. In addition, consider a new PPP project that has no other competitive projects nearby. The investors determine the project quality to maximize their expected profit (Feng et al., 2015). The project quality is determined by the investor's effort. Effort refers to a series of activities to improve the quality or quantity of the project's products or services. The variable that measures effort is called the level of effort (Taylor, 2002; Krishnan et al., 2004). The higher level of effort by investors not only means an increase in operational investment, but also an increase in the level of soft power such as innovative operations. Let us denote the investor's effort level in the operation period of PPP project by $e$. The investors with the high effort level will improve the quality and quantity PPP project products or public services.

Assumption 2. According to Kopalle and Winer (1996), the quality of the product can stimulate market demands. In PPP project, the projects demand is the amount of public use for the project, such as traffic flow, water consumption, etc. The projects demand increases with the improvement of quality. Considering the influence of price and effort level on demand, the demand function is expressed as $D\left(p, q_{e}\right)$, where $p$ is the selling price of the product or service and $q_{e}$ is the quality of the product or service (Feng et al., 2015). In PPP projects, the price has been determined by policies, laws and supervisions to avoid excessive profits generated by project monopoly and harm to public interests. It is usually a fixed value in PPP projects for a certain period. The quality of the project $q_{e}$ is determined by the level of effort of the investor. Therefore, the demand of the project is $D(e), D^{\prime}(e)>0$. Considering the influence of price and effort level on demand and according to Tirole (1994), the normal demand of the project is expressed as $D=\lambda \delta e+\xi$. In the equation, $\lambda(\lambda \geq 0)$ is the comprehensive adjustment coefficient of normal output considering the linear effect of investor effort level on product service or quality and the linear effect of product or service quality on demand. That is, the output efficiency. $\delta(\delta \geq 0)$ is the investment of investors own resources or ability endowment. $\xi$ is a random variable with normal distribution with a mean of basic demand of PPP project $q$ and a variance of $\mu^{2}, \xi \sim N\left(q, \mu^{2}\right)$. PPP as an infrastructure generally has a basic demand from public, and this basic demand is more than zero.

Assumption 3. In PPP projects operational period, the cost of product production or service provision consists of fixed cost and variable cost. The operational fixed cost is the cost that unrelative with the quantity of the usage, such as the salary of the management stuff. The operational variable cost is the cost that relative with the quantity of 
the usage, such as the fee of the material. Besides, considering that the effort made by investors in the project will lead to a decrease in investor resources and an increase in opportunity cost, this cost is regarded as the effort cost $C(e)$ of investors. According to the Taylor (2002) and H-M theoretical model (Holmstrom \& Milgrom, 1987), the investor's effort cost function is $C(e)=\frac{1}{2} m e^{2}$, where $m$ is the coefficient of effort cost, $m>0$. A higher value of $m$ indicates a higher cost for at a specific level of the productive efforts. Therefore, the total cost of the project is $C=C_{f}+d C_{v}+C(e)=C_{f}+C_{v}(\lambda \delta e+\xi)+\frac{1}{2} m e^{2}$.

Assumption 4. When the project revenue is low, the government-controlled utilities bought back by the government are generally inefficient in operation. Tariffs seldom cover the full cost of service (Ehrhardt \& Janson, 2010). Instead, it enlarges the pressure of the government debt and fiscal pressure. Therefore, only when project revenue is high, the government will default to receive cash inflows to ease debt or fiscal pressure. Based on the risksharing rules as well as to protect the public interest, the government receives a share of the excess revenue when the actual earnings of the investors exceed expected returns (Ashuri et al., 2012). The government stipulates the excess revenue sharing boundary $R_{0}$ and the excess revenue sharing ratio $k$ to the investor (Wang \& Liu, 2015). $R_{0}$ is based on the investor's investment cost and reasonable profit margin. When the project revenue is below $R_{0}$, all revenue of the project is owned by the investor. When the project revenue is higher than $R_{0}$, the difference between project revenue and $R_{0}$ will be shared by the government and investors. The ratio shared by the government and investors is $k$ and $1-k$.

Assumption 5. In PPP projects, the government not only considers economic benefits, but also considers social benefits. According to the previous hypothesis, the quality of project products or services will affect the public's demand for projects. For the government, the quantification of social benefits is simplified as a positive correlation with project demand, i.e. $\varphi D(e)=\varphi(\lambda \delta e+\xi), \varphi(\varphi \geq 0)$ is the ratio adjustment coefficient between social benefit and demand. On the one hand, the large demand of projects can reflect the quality level of projects; On the other hand, it can also reflect the coverage of projects to the public, that is, the benefit breadth of the public.

Assumption 6. The government credit represents the willingness and ability of the government to comply with the contract. It is assumed that the government will not choose to default out of self-interest because it can make massive losses $(L)$ larger than the benefit by defaulting, such as decreasing the reputation and political performance. But it does not mean that the government will never default. There are many uncertainties caused by the turbulence in the internal and external environment will impact the behavior of the government default. When the external environment or policy of the project changes, the government is more inclined to default to get inflows to ease debt or fiscal pressure. Therefore, it is assumed that whether a government defaults is not determined by the government but by the internal and external environment. The government credit indicates the possibility of the government default based on the government's fiscal capacity and the history of the government default.

The credit rating reflects the probability of default on the government's debt and thus affects its financing costs (Levy \& Pauzner, 2014). The government has different credit levels and it indicates the possibility of the government default based on the government's fiscal capacity and the history of the government default. From the perspective of investors, government credit is fixed and determines investors perception of government default probability $f(0 \leq f \leq 1)$. Correspondingly, the probability that the government will not default is $1-f(0 \leq 1-f \leq 1)$.

Assumption 7. In PPP project, the government grants the project concession to the investors, and the investors give the products or services of high quality to the public. As a special resource provider, the government can choose the suitable investors at the beginning of the project, but the investors with less resources have no or few other options. Valero (2015) proposed that the PPP projects may lead a government to behave opportunistically because government has more resources to dominate the partnership through the contract, such as choosing to change the contract at any time due to changes in the external environment or other reasons. Therefore, investors may lose faith in the government. It means that the investors believe that the government will change the contract during the operation period to extract project benefits. There are many different forms of the government default, such as renegotiation of the contract, bailout of the private operator or even termination of the contract (Vecchi et al., 2017). Compared with other credit default behaviors, government buyback and direct termination are the most common methods (Yang et al., 2019). Therefore, the government default behaviors can be explained by model that the government buys back the program at a price $R, R \in\left[0, R_{0}\right]$.

\subsection{Model establishment and solution}

In the absence of government credit risk, the government, as the first party, puts forward the boundary and proportion of excess revenue distribution. Investors choose to accept or reject according to the conditions given by the government. If investors choose to reject the conditions, the game ends. Investors will quit the PPP project and the government chooses new investors again. If investors choose to accept the conditions, in the project operation phase, they will choose the best level of effort to maximize their own interests according to the conditions given by the government. However, government defaults occur after investors choose the level of effort. Under the assumption of government default, the real order of the game should be that investors first choose the optimal level of effort, and then the government default. The game order is 
changed. Therefore, this paper turns this uncertainty into a choice under risk. Therefore, this game model introduced "nature" to express the uncertainty of government credit risk. And the rule of natural selection is consistent with the corresponding default probability under the government credit rating.

Most cases of the government default, government will pay the repurchase price based on the investors reasonable profit. Simultaneously, the government-controlled utilities are generally inefficient in operation. Tariffs seldom cover the full cost of service (Ehrhardt \& Janson, 2010). When the project revenue is low, government will not buyback project in general because the difference between revenue and cost needs to be paid by the government, which will increase the pressure of the government debt and fiscal. When the project revenue is high, government buyback projects will obtain all the profits of projects and it will relieve the government debt or fiscal pressure. Therefore, in order to analyze the impact of government credit on the utility of the project during the operation, this paper start with PPP projects with high expected revenue, that is $C_{f}+C_{v}(\lambda \delta e+\xi)+\frac{1}{2} m e^{2}<R_{0}<p(\lambda \delta e+\xi)$.

Based on the above analysis and assumptions, when government doesn't default, the revenue of investors is $\pi_{I 1}=\left[p(\lambda \delta e+\xi)-R_{0}\right](1-k)+R_{0}-C_{f}-C_{v}(\lambda \delta e+\xi)-\frac{1}{2} m e^{2}$. When government default, the revenue of investors is $\pi_{I 2}=R-C_{f}-C_{v}(\lambda \delta e+\xi)-\frac{1}{2} m e^{2}$. In the trading relationship, traders will choose different trading methods according to the credit status of the trading object. Therefore, investors have two choices. Investors choose to trust government that it can comply with the project contract. Another option for investors is to choose not to trust the government. Considering the probability of government default of PPP projects, the comprehensive net income of investors $\pi_{I}$ can be expressed as: $\pi_{I}=(1-f) \pi_{I 1}+f \pi_{I 2}$. Therefore, the expected net income of investors with the government default risks is $E\left(\pi_{I}\right)=E\left[(1-f) \pi_{I 1}+f \pi_{I 2}\right]$.

$E\left(\pi_{I}\right)=(1-f)$

$\left\{\left[p(\lambda \delta e+q)-R_{0}\right](1-k)+R_{0}-C_{f}-C_{v}(\lambda \delta e+q)-\frac{1}{2} m e^{2}\right\}+$

$f\left[R-C_{f}-C_{v}(\lambda \delta e+q)-\frac{1}{2} m e^{2}\right]$.

Similarly, for governments, assume the income is $\pi_{G 1}$ when government doesn't default; Conversely, the income is $\pi_{G 2}$ when the government default. According to the former analysis in PPP project, $\pi_{G 1}$ and $\pi_{G 2}$, respectively, are: $\pi_{G 1}=\left[p(\lambda \delta e+\xi)-R_{0}\right] k+\varphi(\lambda \delta e+\xi)$; $\pi_{G 2}=p(\lambda \delta e+\xi)+\varphi(\lambda \delta e+\xi)-R-L$. Considering the probability of government default of PPP projects, the comprehensive net income of government $\pi_{G}$ can be expressed as: $\pi_{G}=(1-f) \pi_{G 1}+f \pi_{G 2}$. Therefore, the expected net income of governments is $E\left(\pi_{G}\right)=E\left[(1-f) \pi_{G 1}+f \pi_{G 2}\right]$.

$$
\begin{aligned}
& E\left(\pi_{G}\right)=(1-f)\left\{\left[p(\lambda \delta e+q)-R_{0}\right] k+\varphi(\lambda \delta e+q)\right\}+ \\
& f\{p(\lambda \delta e+q)+\varphi(\lambda \delta e+q)-L-R\} .
\end{aligned}
$$

Because both investors and governments assume risk neutrality, in this scenario, the expected utility is equal to the expected net income, i.e. $U_{I}=E\left(\pi_{I}\right), U_{G}=E\left(\pi_{G}\right)$. Therefore, the investors and government strategy choice can be obtained by calculating the model of dynamic game. Equation s.t. $U_{I}$ is the set of constraints that ensures investor's participation in the project (participation constraint), and equation $\max U_{I}$ represents the motivation for investors to maximize their interests (incentive compatibility constraint).

$$
\begin{aligned}
& \max _{k} U_{G}=(1-f)\left\{\left[p(\lambda \delta e+q)-R_{0}\right] k+\varphi(\lambda \delta e+q)\right\}+ \\
& f\{p(\lambda \delta e+q)+\varphi(\lambda \delta e+q)-L-R\} \\
& \text { s.t. } U_{I}=(1-f) \\
& \left\{\left[p(\lambda \delta e+q)-R_{0}\right](1-k)+R_{0}-C_{f}-C_{v}(\lambda \delta e+q)-\frac{1}{2} m e^{2}\right\}+ \\
& {\left[R-C_{f}-C_{v}(\lambda \delta e+q)-\frac{1}{2} m e^{2}\right] \geq 0 ;} \\
& \max U_{I}=(1-f) \\
& \left\{\left[p(\lambda \delta e+q)-R_{0}\right](1-k)+R_{0}-C_{f}-C_{v}(\lambda \delta e+q)-\frac{1}{2} m e^{2}\right\}+ \\
& \left\{\left[R-C_{f}-C_{v}(\lambda \delta e+q)-\frac{1}{2} m e^{2}\right] .\right.
\end{aligned}
$$

The game is solved by inverse induction. $\tau^{*} \in \max U_{I}$ represents the optimal effort level of investors according to the Nash equilibrium. To get the optimal solution of $e$, it is necessary to find the first derivative of the revenue function and make it equal to zero. The reaction function $e^{*}$ is obtained. And then, the government sets the distribution of revenue $k$ in consideration of the choice of the investors optimal level of effort. The same method is used to get the optimal value. According to the firstorder equivalent conditions of $\max _{k} U_{G}, \max _{e} U_{I}$ and s.t. $U_{I}$, the optimal effort level and optimal proportion of the revenue allocation to investors, respectively, are:

$$
\begin{aligned}
& e^{*}=\frac{\lambda \delta\left[(1-f)\left(1-k^{*}\right) p-C_{v}\right]}{m} ; \\
& k^{*}=\frac{p q m-R_{0} m+\lambda^{2} \delta^{2} p\left(p-c_{v}-\varphi-2 p f\right)}{2 \lambda^{2} \delta^{2} p^{2}(1-f)} .
\end{aligned}
$$

\section{Model analysis and discussion}

1. According the participation constraint s.t. $U_{I}$, the maximum of the government default probability $f_{P C}$ that the investors will participate in the PPP project can be obtained: 


$$
f_{P C} \leq \frac{\left[p(\lambda \delta e+q)-R_{0}\right](1-k)+R_{0}-C_{f}-C_{v}(\lambda \delta e+q)-\frac{1}{2} m e^{2}}{\left[p(\lambda \delta e+q)-R_{0}\right](1-k)+R_{0}-R} .
$$

In other words, investors will participate in the PPP project only when the expected default probability of the government represented by the governments credit rating satisfies the participation constraint. Otherwise, investors will not participate in the PPP project.

When $R \geq C_{f}+C_{v}(\lambda \delta e+q)+\frac{1}{2} m e^{2}$, then $f_{P C} \leq 1$. $R \geq C_{f}+C_{v}(\lambda \delta e+q)+\frac{1}{2} m e^{2}$ represents that the price of the government buyback is larger than the total cost of the operation. The investor can profit from participating in PPP projects even if the government default. In this scenario, investors participation in PPP projects is not determined by the governments credit rating, but by the project's costs and benefits.

When $R<C_{f}+C_{v}(\lambda \delta e+q)+\frac{1}{2} m e^{2}$, then

$f_{P C} \leq \frac{\left[p(\lambda \delta e+q)-R_{0}\right](1-k)+R_{0}-C_{f}-C_{v}(\lambda \delta e+q)-\frac{1}{2} m e^{2}}{\left[p(\lambda \delta e+q)-R_{0}\right](1-k)+R_{0}-R}$.

Investors will participate in the PPP project only when the expected default probability of the government is lower than $f_{P C}$. Conversely, if $f>f_{P C}$, then the investor will not choose to participate in PPP projects. In this scenario, investors participation in PPP projects is determined by the governments credit rating and influenced by the project's costs and benefits. $\left[p(\lambda \delta e+q)-R_{0}\right](1-k)+R_{0}$ represents the total revenue of the investors. And $C_{f}+C_{v}(\lambda \delta e+q)+\frac{1}{2} m e^{2}$ represents the total costs of the investors. $f_{P C}$ is directly proportional to the total revenue of investors and inversely proportional to the total cost of investors. That is, the higher the expected revenue of the project, the looser the probability of government default under the restriction of investor participation. The lower the requirement for government credit rating is for investors to choose to participate in PPP projects. When the total project cost is higher, the probability of government default is stricter. The higher the requirement for government credit rating is for investors to choose to participate in PPP projects.

In PPP practice, investors generally have multiple projects involved. When the expected return of a project is not optimistic, investors will choose to focus on other projects and maintain the project with the lowest effort cost. Therefore, there are the minimal of the effort level $e=0$. According the optimal level of the investors effort $e^{*}=\frac{\lambda \delta\left[(1-f)(1-k) p-C_{v}\right]}{m}$, when $e^{*}=0$, then the maximum of the government default probability $f_{I C}$ that the investors will put in the effort in PPP project can be obtained: $f_{I C}=1-\frac{C_{v}}{(1-k) p} \cdot(\lambda \delta e+q) c_{v}$ represents the variable cost of the project, and $p(\lambda \delta e+q)(1-k)$ represents the variable revenue shared by the investors in the excess revenue of the project. Therefore, $\frac{C_{v}(\lambda \delta e+q)}{(1-k) p(\lambda \delta e+q)}=\frac{C_{v}}{(1-k) p}$ represents the cost ratio of the investors. Higher cost ratio indicate less profit for the investors. When the investors cost ratio is higher, $f_{I C}$ is smaller and the condition of $\mathrm{f}<f_{I C}$ is stricter. The cost ratio of investors is positively correlated with the proportion of government participation in the allocation $k$. The greater the proportion of government participation in the allocation, the more stringent the probability of government default is for investors to choose to make efforts.

In summary, the maximum of the government default probability $f_{\max }=\min \left(f_{I C}, f_{P C}\right)$ that the investors will participate and put in the effort in PPP project can be obtained. When $f \leq f_{\max }$, investor will choose the different effort level based on the different of the government credit rating. In addition to this, when $f_{I C} \leq f \leq f_{P C}$, the investors will participate in the PPP project but operate the project with zero effort level and input. In this scenario, the introduction of private investors into project will not improve the project efficiency and cannot realize the value of PPP project. When $f_{P C} \leq f$, investors will refuse to participate in PPP projects.

2. The projects utility is the sum of total revenue and total costs in PPP project. The total revenue of the projects is $(p+\varphi)(\lambda \delta e+q)$. And the total costs of the projects are $C_{f}+C_{v}(\lambda \delta e+q)+\frac{1}{2} m e^{2}+f L$. The project utility represents the efficiency of the project. Therefore, the projects utility $U_{P}$ is denoted: $U_{P}=\left(p+\varphi-C_{v}\right)(\lambda \delta e+q)-C_{f}-\frac{1}{2} m e^{2}-f L$. From the above equation, it can be seen that the probability of government default directly affects the total cost, thus damaging the total utility of the project.

The effort level $\left(e_{p}\right)$ that satisfies the maximization of the total utility of the project can be obtained by taking the first reciprocal of the effort level of the project utility equation and making it equal to zero: $e_{p}=\frac{\lambda \delta\left[p+\varphi-C_{v}\right]}{m}$. When $e \leq e_{p}$, there is a positive correlation between the total project benefit and the investor's effort level. When $e>e_{p}$, there is a negative correlation between the total project benefit and the investor's effort level. It can be obtained from the equation of investors optimal effort level $\left(e^{*}=\frac{\lambda \delta\left[(1-f)(1-k) p-C_{v}\right]}{m}\right)$ that the choice of investors effort level is positively correlated with the perceived probability of government default. Meanwhile, it is obviously that $e^{*}<e_{p}$. Therefore, when government credit causes the level of investor effort to decline, it also reduces the effectiveness of the project. Government credit risk not only increases the cost of the total utility of the project, but also reduces the total output of the project by reducing the level of investor efforts. 
Bring the optimal government allocation $\left(k^{*}=\frac{p q m-R_{0} m+\lambda^{2} \delta^{2} p\left(p-c_{v}-\varphi-2 p f\right)}{2 \lambda^{2} \delta^{2} p^{2}(1-f)}\right)$ into the investor's effort level equation, the optimal effort level of investors is $e^{*}=\frac{\lambda \delta\left[(1-f)\left(1-k^{*}\right) p-C_{v}\right]}{m}=$ $\frac{\lambda^{2} \delta^{2} p\left(p-C_{v}+\varphi\right)-p q m+R_{0} m}{2 \lambda \delta p m}$. It can be seen from the expression of $e^{\star}$ that the level of investors best effort has nothing to do with the probability of government default. In other words, under the contract arrangement of optimal allocation ratio, the choice of investors optimal effort level is not affected by the government credit risk. Furthermore, the output of project utility cannot be affected.

3. When there is no government credit risk $(f=0)$, the investors optimal effort level is $e_{0}=\frac{\lambda \delta\left[\left(1-k_{0}\right) p-C_{v}\right]}{m}$. And the government optimal excess revenue sharing ratio is $k_{0}=\frac{p q m-R_{0} m+\lambda^{2} \delta^{2} p\left(p-c_{v}-\varphi\right)}{2 \lambda^{2} \delta^{2} p^{2}}$. Therefore, the utility of the projects is $U_{P 0}=\left(p+\varphi-C_{v}\right)\left(\frac{\lambda^{2} \delta^{2}\left[\left(1-k_{0}\right) p-C_{v}\right]}{m}+q\right)-$ $C_{f}-\frac{\lambda^{2} \delta^{2}\left[\left(1-k_{0}\right) p-C_{v}\right]^{2}}{2 m}$. And when $0<f<f_{I C}$, the investors will choose the optimal effort level $e^{*}$ based on the government credit. Then $U_{P^{*}}=\left(p+\varphi-C_{v}\right)$ $\left(\frac{\lambda^{2} \delta^{2}\left[(1-f)(1-k) p-C_{v}\right]}{m}+q\right)-C_{f}-\frac{\lambda^{2} \delta^{2}\left[(1-f)(1-k) p-C_{v}\right]^{2}}{2 m}-f L$. The utility loss of the project caused by the government credit risk can be deduced: $\Delta U_{P}=U_{P 0}-U_{P^{*}}$.

When the value of $k$ does not satisfy the optimal value $k^{*}$ and is a constant, $\Delta U_{P}=\frac{\lambda^{2} \delta^{2} p f(1-k)[2 \varphi+2 k p+f p(1-k)]}{2 m}+f L$. When the value of $k$ does satisfy the optimal value $k^{*}, \Delta U_{P}=f L$. The utility loss of the project has nothing to do with the choice of investors because the government adjust the excess revenue distribution when the government credit rating is different to maintain the optimal level of investor effort unchanged. Therefore, in the PPP project contract arrangement, the government distribution ratio should be equal to $k^{*}$ as much as possible. This not only maximizes the utility of the government, but also protects the utility of the project to some extent.

4. Since $k$ represents the proportion of the benefits of government and investors, the range of $k$ is $k \in[0,1]$. When $p q m-R_{0} m+\lambda^{2} \delta^{2} p\left(p-c_{v}-\varphi-2 p f\right) \leq 2 \lambda^{2} \delta^{2} p^{2}(1-f)$

and $p q m-R_{0} m>\lambda^{2} \delta^{2} p\left(p-c_{v}-\varphi-2 p f\right)$, then $k^{*}=\frac{p q m-R_{0} m+\lambda^{2} \delta^{2} p\left(p-c_{v}-\varphi-2 p f\right)}{2 \lambda^{2} \delta^{2} p^{2}(1-f)} \in[0,1]$.
Conversely, if the parameters satisfy the condition $p q m-R_{0} m+\lambda^{2} \delta^{2} p\left(p-c_{v}-\varphi-2 p f\right)>2 \lambda^{2} \delta^{2} p^{2}(1-f)$, then $k^{*}>1$, which is not adapted in actual. In this scenario, the optimal value of the qualified excess return distribution ratio is $k^{\star}=1$. That is, at the beginning of the project, the government and the investors reach an agreement that the government enjoys all the excess return of the project. The investors will operate the project with zero effort level and input $e^{*}=\frac{-C_{\nu} \lambda \delta}{m}=0 \quad\left(k^{*}=0\right.$ because the investor's effort level cannot be negative). If the parameters satisfy the condition $p q m-R_{0} m+\lambda^{2} \delta^{2} p\left(p-c_{v}-\varphi-2 p f\right) \leq 0$, then $k^{\star} \leq 0$. In this scenario, the government will have no way to adjust $k$ to keep the optimal level of investor's efforts in the case of government credit risk. At this time, the government's optimal allocation ratio has lost its ability to control. The government needs to find other ways to compensate for the loss of utility caused by insufficient credit, such as credit enhancement tools.

Furthermore, the equation of optimal government allocation $k(f)$ finds the first derivative of $f$. And it's positive and negative relationships are com-

pared: $k(f)^{\prime}=\frac{p q m-R_{0} m-\lambda^{2} \delta^{2} p\left(p+c_{v}+\varphi\right)}{2 \lambda^{2} \delta^{2} p^{2}(1-f)^{2}}$. When $p q m-R_{0} m-\lambda^{2} \delta^{2} p\left(p+c_{v}+\varphi\right)>0, k(f)$ is proportional to $f$. Conversely, when $p q m-R_{0} m-\lambda^{2} \delta^{2} p\left(p+c_{v}+\varphi\right) \leq 0, k(f)$ is inversely proportional to $f$. Since $k$ represents the proportion of the benefits of government and investors, the range of $k$ is $\mathrm{k} \in[0,1]$. There is a relationship that has to be satisfied: $p q m-R_{0} m+\lambda^{2} \delta^{2} p\left(p-c_{v}-\varphi-2 p f\right) \leq 2 \lambda^{2} \delta^{2} p^{2}(1-f)$. Therefore, $k(f)$ is inversely proportional to $f$. This is not difficult to understand through the above analysis. It demonstrates that the government will decrease the excess revenue distribution when the government credit rating is low to maintain the investors effort level unchanged.

5. The government utility represents the net revenue of government in PPP projects. If there is no government credit risk $(f=0)$, the utility of government in PPP project is $U_{G 0}=\left[p(\lambda \delta e+q)-R_{0}\right] k_{0}+\varphi(\lambda \delta e+q)$. When $0<f<f_{\text {IC }}$, the investors will choose the optimal effort level $e_{0}$ to deal with the risk and $e_{0}=e^{\star}$ after considering the effect of the governments optimal allocation ratio. Then $U_{G^{*}}=(1-f)\left\{\left[p(\lambda \delta e+q)-R_{0}\right] k^{*}+\varphi(\lambda \delta e+q)\right\}+$ $f\{p(\lambda \delta e+q)+\varphi(\lambda \delta e+q)-L-R\}$. The utility loss of the government caused by the government credit risk can be deduced: $\Delta U_{G}=U_{G 0}-U_{G^{*}}=f(L+R)+\left(k^{*}-k_{0}-f k^{*}\right) R_{0}$. Since $k^{*}-k_{0}-f k^{*}+f=0, k^{*}-k_{0}-f k^{*}=-f, \Delta U_{G}=$ $f\left(L+R-R_{0}\right)$. Under the contract arrangement of optimal allocation ratio, the loss of government utility due to government credit risk is $f\left(L+R-R_{0}\right)$. As assumed above, $L$ is large, so the utility loss of the government is a positive value. This is positively correlated with the probability of government default. That is, the higher the probability of government default, the greater the loss of utility of the government. 
In the credit markets, there are many credit enhancement's instruments. Credit enhancements relying on third-party agency guarantees to enhance their own credit rating are also considered to solve the problem of government credit risk in PPP projects (Chowdhury et al., 2015). Credit enhancement can not only attract investors to participate in PPP projects, but also reduce the probability of government default perceived by both sides. The government can use credit enhancement to minimize the utility losses by reducing the probability of default. Therefore, the decision on credit enhancement can be made by comparing the price of purchasing credit enhancement instruments with the utility loss reduced by the government after the credit enhancement.

\section{Numerical simulation}

When PPP projects are faced with government credit risks, investors will reduce the level of effort according to the perceived probability of government default, thereby damaging the project utility and further damaging the government and public interests. An appropriate revenue distribution ratio can help the government to motivate investors, so as to keep the level of investor effort unchanged. And minimize the loss of government credit risk to the project. In order to describe the models proposed above more intuitively and further illustrate the application of the implications, a numerical simulation is furnished in detail.

Given that the probability of the government default $(f)$ will directly determine the level of investors effort $(e)$ in PPP projects to some extent, then the relationships between the optimal allocation proportion $(k)$ and the optimal effort level (e) accordingly have been explained in different government credit rating, as stated in equation $k^{\star}$ and $e^{\star}$. Assumed that there is a heating PPP project. The project is expected to have a construction cost of 350 million RMB. The government granted investors a 25-year concession period, of which the construction period is 3 years. The annual fixed operating cost of the project is 2 million $\mathrm{RMB}\left(c_{f}=200\right)$. The basic demand of the project is $200,000(q=20)$ and the unit price is $15 \mathrm{RMB}(p=15)$. The excess revenue sharing boundary is 3.0 million RMB $\left(R_{0}=300\right)$. Basic parameters of the investor's operation project are $c_{v}=1, m=2, \lambda=1.5, \delta=2$. Basic parameters of the government are $\varphi=1.2, L=200$ (2 million $\mathrm{RMB}$ ).

Under the condition that the government's excess revenue distribution ratio $k$ remains unchanged, the project utility is inversely proportional to the probability of government default. In other words, when investors perceive a high probability of default due to a low government credit rating, they will choose to reduce the level of project effort and will lead to a reduction in project utility. This can be seen from the horizontal comparison of the data in Table 1 . Similarly, when the default probability of a project is determined, the project utility is inversely proportional to the proportion of the government's excess revenue distribution. In other words, when the government allocates less excess returns from the project, the investors will choose to increase the project effort level and lead to the improvement of project utility. This can be seen from the longitudinal comparison of the data in Table 1.

Therefore, In order to ensure the maximization of its own interests and to minimize the loss of project utility caused by the government's credit risk, the government can balance the negative utility of the project caused by the government's probability of default by adjusting the proportion of excess revenue distribution. As can be seen from the column $k=k^{\star}$ in Table 1, when the government's excess revenue distribution ratio changes with the default probability of the project based on the optimal distribution ratio formula, the investor's effort level will not change with the default probability of the project. This reduces the loss of project utility due to government credit risk.

Table 1 . The impact of default probability and revenue distribution on the project

\begin{tabular}{|c|c|c|c|c|c|c|c|}
\hline \multicolumn{2}{|c|}{$f$} & 0.00 & 0.10 & 0.20 & 0.30 & 0.40 & 0.50 \\
\hline \multirow{3}{*}{$k=0.2$} & $e^{*}$ & 16.50 & 14.70 & 12.90 & 11.10 & 9.30 & 7.50 \\
\hline & $U_{p}$ & 584.15 & 538.23 & 485.83 & 426.95 & 361.59 & 289.75 \\
\hline & $U_{G}$ & 231.90 & 244.14 & 243.42 & 229.74 & 203.10 & 163.50 \\
\hline \multirow{3}{*}{$k=0.4$} & $e^{\star}$ & 12.00 & 10.65 & 9.30 & 7.95 & 6.60 & 5.25 \\
\hline & $U_{p}$ & 507.20 & 456.22 & 401.59 & 343.32 & 281.40 & 215.84 \\
\hline & $U_{G}$ & 283.20 & 264.80 & 239.10 & 206.12 & 165.84 & 118.28 \\
\hline \multirow{3}{*}{$k=0.6$} & $e^{*}$ & 7.50 & 6.60 & 5.70 & 4.80 & 3.90 & 3.00 \\
\hline & $U_{p}$ & 389.75 & 341.40 & 291.43 & 239.84 & 186.63 & 131.80 \\
\hline & $U_{G}$ & 253.50 & 219.84 & 182.94 & 142.80 & 99.42 & 52.80 \\
\hline \multirow{4}{*}{$k=k^{*}$} & $k^{*}$ & 0.43 & 0.36 & 0.28 & 0.18 & 0.04 & -0.15 \\
\hline & $e^{*}$ & 11.40 & 11.40 & 11.40 & 11.40 & 11.40 & 11.40 \\
\hline & $U_{p}$ & 493.88 & 473.88 & 453.88 & 433.88 & 413.88 & 393.88 \\
\hline & $U_{G}$ & 283.92 & 265.92 & 247.92 & 229.92 & 211.92 & 231.54 \\
\hline
\end{tabular}




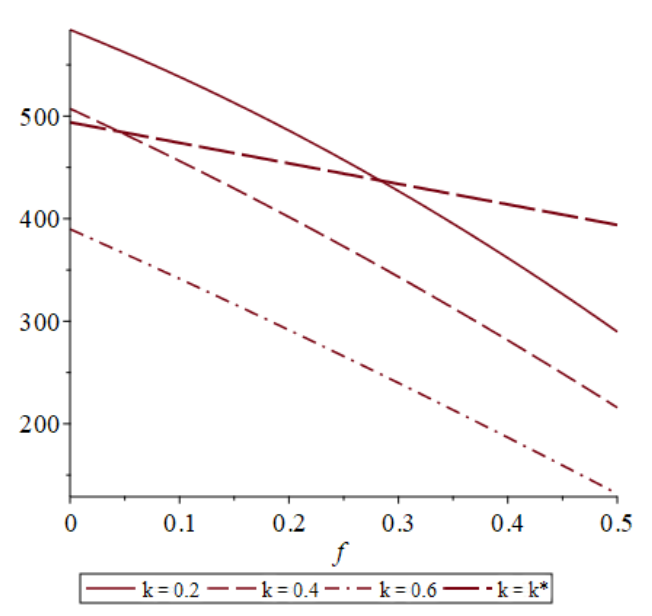

Figure 1 . The impact of default probability and revenue distribution on the project utility

If the increase or decrease in the above data is not obvious, this paper illustrates the impact of default probability and revenue distribution on the project utility more clearly by Figure 1 . When $k=k^{\star}$, the utility of the project is reduced by the loss caused by the probability of government default. In this scenario, the absolute value of government utility may not be the greatest, but the reduction in government utility must be the smallest. To some extent, this weakens the impact of government credit risk on the project.

It is worth mentioning that the government's method of reducing the impact of credit risk on the project by adjusting the allocation ratio is not necessarily effective. If $k^{*} \leq 0$, the government will have no way to adjust $k$ to keep the optimal level of investor's efforts in the case of government credit risk. At this time, the government's optimal allocation ratio has lost its ability to control. Therefore, this paper demonstrates the relationship between the optimal allocation ratio and default probability by Figure 2 .

Under the data assumptions above, when there is no government credit risk $(f=0)$, the government has the largest allocation ratio $\left(k_{\max }^{*}=0.43\right)$. Moreover, as the probability of government default increases, the government's optimal excess return distribution ratio decreases. When $f=0.43$, the government has the lowest allocation ratio $\left(k_{\min }^{*}=0\right)$. Therefore, when $f>0.43$, the government's optimal allocation ratio has lost its ability to control. The curve in Figure 2 is the relationship between the optimal allocation ratio and default probability. When the distribution ratio takes a value on the curve, it not only maximizes the utility of the government, but also protects the utility of the project to some extent. When the distribution ratio is taken in the curve, it will increase the project utility but decrease the government utility. When the distribution ratio is taken outside the curve, it will not only reduce the overall utility of the project, but also reduce the utility of the government.

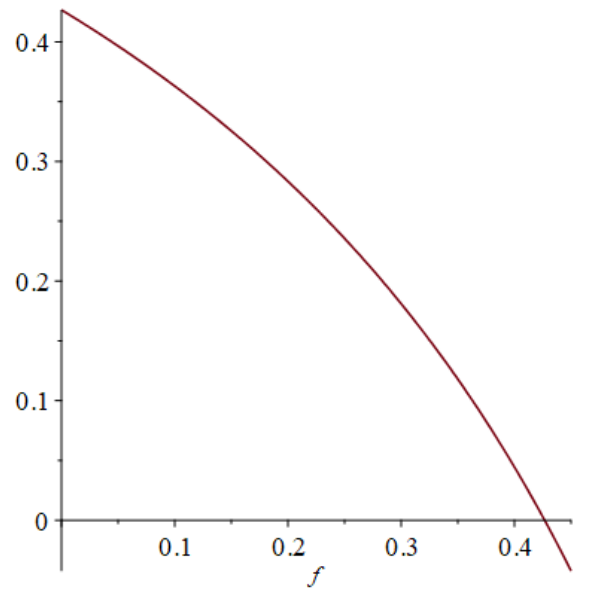

Figure 2. The relationship between the optimal allocation ratio and default probability

When the government's optimal allocation ratio has lost its ability to control, the government can use credit enhancement to minimize the utility losses by reducing the probability of default. Credit enhancement can not only enhance government credit to attract investors to participate in PPP projects, but also reduce the probability of government default perceived by both sides. The government utility can be increased by reducing the probability of government default under the condition of keeping the proportion of project revenue distribution unchanged. This can be used to evaluate whether the credit enhancement tool is worth purchasing. When the cost of purchasing a credit enhancement tool is greater than the increased government utility, it can be purchased. When the cost of purchasing a credit enhancement tool is less than the increased government utility, it is not worth purchasing. If the government's original default probability was 0.2 , its upgrade to 0.0 will increase the utility by 36 ten-thousands RMB based on Table 1 . Then when the cost of credit upgrade is greater than 36 ten-thousands RMB, the government chooses not to do it. When the cost of credit enhancement is less than 36 ten-thousands RMB, the government can choose to purchase credit enhancement tools to increase the utility. This provides the basis for government decision-making.

\section{Conclusions}

There are many risks in PPP projects. Among them, government default has become one of the key risks because of its high frequency and large losses. The government's default will lead to the termination of the financial feasibility of the project, resulting in investors not only unable to obtain the expected benefits, but also may fail to recover the costs paid. This will lead investors to reduce operating costs as much as possible and even damage the quality of the project, further damaging the social benefit. Therefore, it is important for governments and investors 
to understand the causal relationship between government credit risk and project utility. Given the relationship forged by governments (as a principal) and private investors (as an agent), models are constructed to design the optimal contract arrangements in the government credit risk scenarios using principal-agent theory to explore the quantity relationship of the government credit risk and the project utility.

Results show that the investors will consider the government's credit risk and choose different strategies to maximize their own profits. After comprehensively considering parameters such as project output and cost, there is a maximum government default probability $f_{P C}$ for investors participating in PPP projects. When the government's probability of default exceeds $f_{P C}$, investors will refuse to participate in PPP projects and hinder the development of PPP projects. When the government's probability of default is less than $f_{P C}$, investors will choose to participate in the project. However, due to the risk perception, investor will adjust their level of effort to maximize the utility. The greater government credit risk means that investors are less likely to get revenue from projects. In this scenario, investors will reduce input in the project, such as reduce the effort level. This caused a loss of project utility eventually.

And then, this paper found that the distribution ratio that satisfies the maximization of government utility will decrease with the increase of the probability of government default within a certain range. The adjustment of the distribution ratio has an incentive effect on investors. The increase in the level of effort due to incentives exactly offsets the reduction of the level of effort by investors to deal with credit risks. This means that the government's timely modification of the contract allocation ratio based on its own credit rating can offset the negative impact of its credit risk on the effectiveness of the project. And the role of the government in adjusting the optimal proportional distribution is limited through calculation and analysis. In this scenario, government purchase of credit enhancement tools can be one solution. And the model's quantitative calculation of government utility can be used as a theoretical basis for government decision-making.

Previous studies focused on the impact of credit risk on project financing costs and bidding prices in the early stage of the project and ignored the impact of credit risk on investor behavior during the operation period. Different from previous studies, this paper considered the investors will choose different behavior strategies (the effort level) to maximize profits based on the government's credit rating in operation stage. This study contributes to the body of knowledge by quantitatively demonstrating the impact of credit risk on project utility during PPP project operation and designing the optimal contracts strategy for governments. And in view of the problem of limited government contract control capacity, suggestions for credit enhancement were put forward. The findings effectively provide some new insights for governments and private investors considering the government credit risk.

The limitation of this paper is that this paper assumes that investors' perception of the government's default probability depends solely on government credit ratings. But in facts this may have more influence factors.

\section{Acknowledgements}

The authors thank the National Natural Science Foundation of China [grant number 71571149]. We also thank the anonymous reviewers for their comments.

\section{Funding}

This work was supported by the National Natural Science Foundation of China under Grant [number 71571149].

\section{Author contributions}

Yining Zhou and Jicai Liu conceived the study and were responsible for the research design and methodology. Yining Zhou were responsible for the model development and numerical example. Jicai Liu and Yining Zhou developed the data analysis and the conclusion.

\section{Disclosure statement}

The authors declare that they have no competing financial, professional, or personal interests from other parties.

\section{References}

Ashuri, B., Kashani, H., Molenaar, K. R., Lee, S., \& Lu, J. (2012). Risk-neutral pricing approach for evaluating BOT highway projects with government minimum revenue guarantee options. Journal of Construction Engineering and Management, 138(4), 545-557.

https://doi.org/10.1061/(ASCE)CO.1943-7862.0000447

Blanc-Brude, F., \& Strange, R. (2010). How banks price loans to public-private partnerships: evidence from the European markets. Journal of Applied Corporate Finance, 19(4), 94-106. https://doi.org/10.1111/j.1745-6622.2007.00163.x

Bing, L., Akintoye, A., Edwards, P. J., \& Hardcastle, C. (2005). The allocation of risk in PPP/PFI construction projects in the UK. International Journal of Project Management, 23(1), 25-35. https://doi.org/10.1016/j.ijproman.2004.04.006

Chen, O. (2009). Can the pilot BOT project provide a template for future projects? A case study of the Chengdu No. 6 Water Plant B Project. International Journal of Project Management, 27(6), 573-583.

https://doi.org/10.1016/j.ijproman.2008.10.006

Cheng, Z., Ke, Y., Lin, J., Yang, Z., \& Cai, J. (2016). Spatiotemporal dynamics of public private partnership projects in China. International Journal of Project Management, 34(7), 1242-1251. https://doi.org/10.1016/j.ijproman.2016.05.006

Chowdhury, A. N., Chen, P. H., \& Tiong, R. L. K. (2011). Analysing the structure of public-private partnership projects using network theory. Construction Management and Economics, 29(1-3), 247-260.

https://doi.org/10.1080/01446193.2010.537354 
Chowdhury, A. N., Chen, P. H., \& Tiong, R. L. K. (2015). Credit enhancement factors for the financing of independent power producer (IPP) projects in Asia. International Journal of Project Management, 33(7), 1576-1587.

https://doi.org/10.1016/j.ijproman.2015.04.007

Ehrhardt, D., \& Janson, N. (2010). Can regulation improve the performance of government-controlled water utilities? Water Policy, 12(S1), 23-40. https://doi.org/10.2166/wp.2010.112

Feng, Z., Zhang, S. B., \& Gao, Y. (2015). Modeling the impact of government guarantees on toll charge, road quality and capacity for build-operate-transfer (BOT) road projects. Transportation Research Part A: Policy and Practice, 78, 54-67. https://doi.org/10.1016/j.tra.2015.05.006

Gao, Y., Wang, S., \& Feng, K. (2017). Failure reasons and enlightenment of PPP project in India Delhi airport. Construction Economy, 38(6), 27-31.

https://doi.org/10.14181/j.cnki.1002-851x.201706027

Girardone, C., \& Snaith, S. (2011). Project finance loan spreads and disaggregated political risk. Applied Financial Economics, 21(23), 1725-1734.

https://doi.org/10.1080/09603107.2011.577006

Grammenos, C. T., Nomikos, N. K., \& Papapostolou, N. C. (2008). Estimating the probability of default for shipping high yield bond issues. Transportation Research Part E: Logs and Transportation Review, 44(6), 1123-1138.

https://doi.org/10.1016/j.tre.2007.10.005

Holmstrom, B., \& Milgrom, P. (1987). Aggregation and linearity in the provision of intertemporal incentives. Econometrica, 55(2), 303-328. https://doi.org/10.2307/1913238

Hwang, B. G., Zhao, X., \& Gay, M. J. S. (2013). Public private partnership projects in Singapore: factors, critical risks and preferred risk allocation from the perspective of contractors. International Journal of Project Management, 31(3), 424-433. https://doi.org/10.1016/j.ijproman.2012.08.003

Iossa, E., \& Martimort, D. (2015). The simple microeconomics of public-private partnerships. Journal of Public Economic Theory, 17(1), 4-48. https://doi.org/10.1111/jpet.12114

Kadefors, A. (2004). Trust in project relationships-inside the black box. International Journal of Project Management, 22(3), 175-182. https://doi.org/10.1016/S0263-7863(03)00031-0

Kang, C. C., \& Feng, C. M. (2009). Risk measurement and risk identification for BOT projects: a multi-attribute utility approach. Mathematical \& Computer Modelling, 49(9-10), 1802-1815. https://doi.org/10.1016/j.mcm.2008.10.015

Ke, Y., Wang, S. Q., Chan, A. P. C., \& Lam, P. T. I. (2010). Preferred risk allocation in China's public-private partnership (PPP) projects. International Journal of Project Management, 28(5), 482-492. https://doi.org/10.1016/j.ijproman.2009.08.007

Ke, Y., Wang, S. Q., Chan, A. P. C., \& Cheung, E. (2011). Understanding the risks in China's PPP projects: ranking of their probability and consequence. Engineering Construction and Architectural Management, 18(5), 481-496.

https://doi.org/10.1108/09699981111165176

Keers, B. B. M., \& van Fenema, P. C. (2018). Managing risks in public-private partnership formation projects. International Journal of Project Management, 36(6), 861-875. https://doi.org/10.1016/j.ijproman.2018.05.001

Kopalle, P. K., \& Winer, R. S. (1996). A dynamic model of reference price and expected quality. Marketing Letters, 7(1), 41-52. https://doi.org/10.1007/BF00557310

Kong, D., Tiong, R. L. K., Cheah, C. Y. J., Permana, A., \& Ehrlich, M. (2008). Assessment of credit risk in project finance. Journal of Construction Engineering and Management,
134(11), 876-884. https://doi.org/10.1061/(ASCE)07339364(2008)134:11(876)

Krishnan, H., Kapuscinski, R., \& Butz, D. A. (2004). Coordinating contracts for decentralized supply chains with retailer promotional effort. Management Science, 50(1), 48-63. https://doi.org/10.1287/mnsc.50.1.48.27052

Lara-Rubio, J., Rayo-Cantón, S., Navarro-Galera, A., \& Buendia-Carrillo, D. (2017). Analysing credit risk in large local governments: an empirical study in Spain. Local Government Studies, 43(2), 194-217.

https://doi.org/10.1080/03003930.2016.1261700

Levy, N., \& Pauzner, A. (2014). Government's credit-rating concerns and the evaluation of public projects. Journal of Public Economics, 115, 117-130.

https://doi.org/10.1016/j.jpubeco.2013.11.007

Li, S., Abraham, D., \& Cai, H. (2017). Infrastructure financing with project bond and credit default swap under public-private partnerships. International Journal of Project Management, 35(3), 406-419. https://doi.org/10.1016/j.ijproman.2017.01.005

Marques, R. C., \& Berg, S. (2012). Risks, contracts, and privatesector participation in infrastructure. Journal of Construction Engineering and Management, 137(11), 925-932. https://doi.org/10.1061/(ASCE)CO.1943-7862.0000347

Regan, M., Smith, J., \& Love, P. (2009, September 10-11). Public private partnership: what does the future hold? In RICS (Ed.), The Construction and Building Research Conference of the RICS (pp. 462-474). RICS.

http://hdl.handle.net/20.500.11937/41940

Ryan, B. (2007). How can the corporate sector concepts of 'reputation' and 'trust' be used by local government? A study to establish a model of reputation management for local government. Asia Pacific Public Relations Journal, 8, 37-75. https://core.ac.uk/display/11038405

Sachs, T., Tiong, R., \& Wang S, Q. (2007). Analysis of political risks and opportunities in public private partnerships (PPP) in China and selected Asian countries: survey results. Chinese Management Studies, 1(2), 126-148. https://doi.org/10.1108/17506140710758026

Song, J., Song, D., \& Wang, D. (2009). The operational risk of Quanzhou Citong Bridge BOT project. Journal of Management Case Studies, 2(3), 196-204. http://en.cnki.com.cn/Article_en/CJFDTOTAL-GLAL200903007.htm

Song, J., Hu, Y., \& Feng, Z. (2018). Factors influencing early termination of PPP projects in China. Journal of Management in Engineering, 34(1), 05017008.

https://doi.org/10.1061/(ASCE)ME.1943-5479.0000572

Soomro, M. A., \& Zhang, X. (2016). Evaluation of the functions of public sector partners in transportation public-private partnerships failures. Journal of Management in Engineering, 32(1), 04015027.

https://doi.org/10.1061/(ASCE)ME.1943-5479.0000387

Tang, L. Y., Shen, Q., \& Cheng, E. W. L. (2010). A review of studies on public-private partnership projects in the construction industry. International Journal of Project Management, 28(7), 683-694. https://doi.org/10.1016/j.ijproman.2009.11.009

Taylor, T. A. (2002). Supply chain coordination under channel rebates with sales effort effects. Management Science, 48(8), 992-1007. https://doi.org/10.1287/mnsc.48.8.992.168

Tirole, J. (1994). The internal organization of government. $O x$ ford Economic Papers, 46(1), 1-29.

https://doi.org/10.1093/oxfordjournals.oep.a042114 
Tserng, H. P., Liao, H. H., Jaselskis, E. J., Tsai, L. K., \& Chen, P. C. (2012). Predicting construction contractor default with barrier option model. Journal of Construction Engineering and Management, 138(5), 621-630. https://doi.org/10.1061/(ASCE)CO.1943-7862.0000465

Tserng, H. P., Liao, H. H., Tsai, L. K., \& Chen, P. C. (2011). Predicting construction contractor default with option-based credit models-models' performance and comparison with financial ratio models. Journal of Construction Engineering and Management, 137(6), 412-420. https://doi.org/10.1061/(ASCE)CO.1943-7862.0000311

Uiterwijk, D., Soeters, J., \& Fenema, P. V. (2013). Aligning national "logics" in a European military helicopter program. Defense \& Security Analysis, 29(1), 54-67. https://doi.org/10.1080/14751798.2013.760248

Valero, V. (2015). Government opportunism in public-private partnerships. Journal of Public Economic Theory, 17(1), 111135. https://doi.org/10.1111/jpet.12105

Vecchi, V., Hellowell, M., Croce, R. D., \& Gatti, S. (2017). Government policies to enhance access to credit for infrastructure-based PPPs: an approach to classification and appraisal. Public Money and Management, 37(2), 133-140. https://doi.org/10.1080/09540962.2016.1266173

Voelker, C., Permana, A., Sachs, T., \& Tiong, R. (2008). Political risk perception in Indonesian power projects. Journal of Financial Management of Property and Construction, 13(1), 18-34. https://doi.org/10.1108/13664380810882057

Wang, W. C. (2002). Sim-utility: model for project ceiling price determination. Journal of Construction Engineering and Management, 128(1), 76-84. https://doi.org/10.1061/(ASCE)0733-9364(2002)128:1(76)

Wang, S. Q., Tiong, R. L. K., Ting, S. K., \& Ashley, D. (2000). Evaluation and management of political risks in China's BOT projects. Journal of Construction Engineering and Management, 126(3), 242-250.

https://doi.org/10.1061/(ASCE)0733-9364(2000)126:3(242)
Wang, X., Shi, L., Wang, B., \& Kan, M. (2019). A method to evaluate credit risk for banks under PPP project finance. Engineering Construction and Architectural Management, 27(2), 483-501. https://doi.org/10.1108/ECAM-06-2018-0247

Wang, Y., \& Liu, J. (2015). Evaluation of the excess revenue sharing ratio in PPP projects using principal-agent models. International Journal of Project Management, 33(6), 1317-1324. https://doi.org/10.1016/j.ijproman.2015.03.002

Wibowo, A., Permana, A., Kochendörfer, B., Kiong, R. T. L., Jacob, D., \& Neunzehn, D. (2012). Modeling contingent liabilities arising from government guarantees in Indonesian BOT/PPP toll roads. Journal of Construction Engineering and Management, 138(12), 1403-1410. https://doi.org/10.1061/(ASCE)CO.1943-7862.0000555

Yan, M., Pong, C., \& Lo, W. (2011). Utility-based multicriteria model for evaluating BOT projects. Technological and Economic Development of Economy, 17(2), 207-218. https://doi.org/10.3846/20294913.2011.580585

Yang, J., Song, L., \& Xing, Z. (2019). Credit default of local public sectors in Chinese government-pay PPP projects: evidence from ecological construction. Advances in Civil Engineering, 2019, 2138525. https://doi.org/10.1155/2019/2138525

Yuan, J. F., Skibniewski, M. J., Li, Q., \& Shan, J. (2010). The driving factors of China's public-private partnership projects in metropolitian transportation systems: public sector's viewpoint. Journal of Civil Engineering and Management, 16(1), 5-18. https://doi.org/10.3846/jcem.2010.01

Zhang, S., Chan, A. P. C., Feng, Y., Duan, H., \& Ke, Y. (2016). Critical review on PPP research - a search from the Chinese and international journals. International Journal of Project Management, 34(4), 597-612. https://doi.org/10.1016/j.ijproman.2016.02.008

Zhang, X. (2005). Critical success factors for public-private partnerships in infrastructure development. Journal of Construction Engineering and Management, 131(1), 3-14. https://doi.org/10.1016/10.1061/(ASCE)0733-9364(2005)131:1(3) 